\title{
Dynamic Pricing: Some Thoughts and Analysis
}

\author{
Dan Bauer \\ Bellarmine University \\ Michelle C. Reiss \\ Spalding University
}

This research examines the market efficiency of concert tickets, particularly the lost revenue in high demand events where dynamic pricing was not used and tickets were inefficiently priced. The paper includes review of related literature and an event study of initial and secondary market prices of tickets to the summer 2013, 2016, and 2018 Pearl Jam concerts at Wrigley Field in Chicago.

\section{INTRODUCTION}

The opposite of fixed rate pricing, dynamic pricing is an approach to setting the cost for a product or service that is highly flexible. The goal of dynamic pricing is to allow a company that sells goods or services online to adjust prices on the fly in response to market demands. In sum, dynamic pricing is the application of data management systems and pricing strategies to allocate the right capacity to the right customer at the right time (Kimes and Wirtz, 2003).

The intent of this paper is to examine dynamic pricing, efficient markets and the impact of underpriced concert tickets and the effects of not using a dynamic pricing model for high demand concerts. Some stars such as Taylor Swift, U2, and the Eagles have moved to a dynamic pricing strategy, where concert tickets, like airline seats, constantly change in price with market demand - leading to ticket availability until the concert and selling tickets on secondary market sites like StubHub. Others, such as Pearl Jam and the Foo Fighters, have not used the dynamic pricing model.

An efficient market means that prices fully and correctly reflect all available information at all times. Market efficiency, therefore, discusses the movement in prices with respect to information. Thus, at any point in time, the market price should be the correct price and the amount of competition in looking for information makes the market efficient. Thus, a dynamic pricing strategy ties directly to the assumption of market efficiency.

The Efficient Market Hypothesis (and markets for financial assets) has been researched extensively; however, the Efficient Market Hypothesis has not been applied as often to the market for real assets. With real assets, we rely on competition and knowledge of market conditions (information) to ensure the price is correct. If these conditions are not in place, you have a market for "lemons", and inefficiency in market prices relative to true value. The same holds true for concert tickets, leading to scalping opportunities.

This research examines the market efficiency of concert tickets, particularly the lost revenue in high demand events where dynamic pricing was not used and tickets were inefficiently priced. The paper 
includes review of related literature and an event study of initial and secondary market prices of tickets to the summer 2013, 2016, and 2018 Pearl Jam concerts at Wrigley Field in Chicago.

\section{LITERATURE REVIEW}

Dynamic pricing revenue models are extensively used in the airline, hotel and rental car industries (Hanks, et al., 1992; Smith et al 1992; Carroll and Grimes, 1995). These models have only recently been implemented on a large scale in the concert industry, and as shown in this paper's analysis potential revenue gains can be substantial. Dynamic pricing models tie directly to the financial concept of market efficiency. In an efficient market, the market price should be the correct price, and movements in price occur with respect to new information and the competition looking for information. Thus, as with dynamic pricing models, in efficient markets prices will constantly change based on new information.

Research into dynamic pricing in the concert ticket market has focused on variables that impact the perceived value of a ticket, and initial ticket pricing. Shapiro, Drayer and Dwyer, (2016) noted time, fairness, seat location, and ticket demand influenced perceived value of the ticket. Courty (2003) found that ticket prices for live events are usually underpriced at initial sale. While, Krueger and Pray (2008) concluded that tickets are set below market level to attract buyers and create buzz.

Kimes and Wirtz (2003) examined the perceived fairness of revenue management in the golf industry and explained experience in other industries has shown revenue management (dynamic pricing) can increase revenue without affecting customer satisfaction. Gelbrich (2011) found with the help of a new generation of algorithms online retailers are capable of changing prices on the same product depending on demand and on consumers' individual characteristics. Weisstein, Monroe and Kukar-Kinney (2013) identified tactical ways to implement dynamic pricing while mitigating consumers' possible negative reactions. They also found that consumers' overall perceptions of dynamic pricing are influenced by perceived differences between their transactions and others.

The concert ticket market includes both primary market sales and secondary market sales. Historically, much of the secondary market exchange took place through brokers or in person in front of the venue the day of the show notes Seabrook (2009). Since the late 1990s, secondary market sales have increasingly moved online, and occur either through a secondary market website owned by the primary ticketing vendor, by third party websites specifically for ticket resale, or by craigslist.

From an economic perspective, brokers in the secondary market practice arbitrage by taking advantage of the price difference between face value tickets and the true market price of the tickets on the secondary market (Courty, 2000). They can do so because promoters may ignore market factors that affect price. Also, if promoters do not price tickets at enough price points brokers can typically buy tickets for the best seats in a section at a price representing the average section's seat and resell them at their true value.

Across both economic and marketing literature, strategic pricing in the concert ticket market has been examined in primary and secondary markets. In both markets, ticket pricing is influenced by economic and organizational factors combined with the perceived value that fans place on individual tickets (Volpano, 2003).

Volpano (2003) explained that in order to maximize revenue, ticket prices should reflect the amount of buyer demand as well as venue and artist characteristics. However, below market value ticket pricing has been found to occur in the primary ticket market and has led to economic research in the area of illogical pricing in the concert business. Drayer and Shapiro (2009) noted that ticket prices in the live entertainment industry are usually priced at a suboptimal level, where promoters try to find a balance between profit maximization and demand. Many artists in an effort to appear like they are being fair to fans and to avoid being seen as gouging fans will set prices below the profit maximizing level (Krueger and Pray, 2008).

Krueger and Pray (2008) also discussed several reasons why variations occur in secondary ticket market pricing. One reason is that tickets are set below the market clearing level to attract buyers and create a "buzz" that increases demand in the secondary market. Another reason is that fans affect the 
quality of the event, and concert promoters price tickets to attract the most eager fans. Finally, tickets are resold because buyer's plans or interest

A central theme of much of the academic and financial economics research since the 1960s has been the efficiency of the capital markets. An efficient market means that prices fully and correctly reflect all available information at all times. Market efficiency, therefore, discusses the movement in prices with respect to information. Thus, at any point in time, the market price should be the correct price and the amount of competition in looking for information makes the market efficient.

Many of the studies (including Rozeff and McKinney, 1976; and De Bont and Thaler, 1989) in this area have been applied to financial markets and have documented anomalies to the hypothesis. These include:

- A reversal effect, poorly performing stocks in one period tend to become well performing stocks in the next period and vice-versa.

- The January effect, returns are higher in January than in any other month.

- The day of the week (weekend) effect, returns are low and gradually increase as the week progresses.

- The size effect, stocks with small market capitalization (value) generate higher returns than stocks with large market capitalization (value).

- The monthly effect, returns are higher during the early part of the month and are higher than returns during the latter part.

- Holiday effect, returns are unusually high prior to holidays.

- Overreaction effect, where investors react disproportionately to new information about a given security. This will cause the security's price to change dramatically, so that the price will not fully reflect the security's true value immediately following the event. Typically, the price swing from overreaction is not long lasting, as the stock price will tend to return back to its true value over time.

\section{ANALYSIS}

In an attempt to explain pricing trends in light of the efficient market hypothesis, and potential lost revenue by not using a dynamic pricing model this paper examines secondary market trends in ticket prices of a series of high demand concerts that did not use dynamic pricing - and estimates the corresponding lost revenue.

In 2013, 2016, and 2018 the rock band Pearl Jam held a series of highly anticipated and high-ticket demand concerts at Wrigley Field in Chicago, IL. Table 1 displays results from primary market sales to each concert. Monthly average selling prices were also collected from EBay for Pearl Jam's 2013, 2016 and 2018 concerts. Table 2 displays the secondary market average selling prices by year.

TABLE 1

\section{PRIMARY MARKET SALES}

\begin{tabular}{|lr|l|l|l|}
\hline Concert & Face Value of Tickets & Sell Out Time & Initial Sale \\
\hline Wrigley 2013 & $\$ 77$ and \$57 & Immediately & February 2013 \\
\hline $\begin{array}{l}\text { Wrigley } \\
\text { shows })\end{array}$ & $(2$ & $\$ 85$ and \$75 & Immediately & February 2016 \\
\hline $\begin{array}{l}\text { Wrigley } \\
\text { shows })\end{array}$ & $(2$ & $\$ 129.50$ & Immediately & February 2018 \\
\hline
\end{tabular}


TABLE 2

SECONDARY MARKET AVERAGE SELLING PRICES

\begin{tabular}{|l|l|l|l|}
\hline & $\begin{array}{c}\text { EBay Selling Prices 2013 } \\
\text { (1 show) }\end{array}$ & \multicolumn{1}{|c|}{$\begin{array}{c}\text { EBay Selling Prices 2016 } \\
\text { (2 shows) }\end{array}$} & $\begin{array}{c}\text { EBay Selling Prices 2018 } \\
\text { (2 shows) }\end{array}$ \\
\hline February & $\$ 316$ & $\$ 236$ & $\$ 267$ \\
\hline March & $\$ 273$ & $\$ 209$ & $\$ 278$ \\
\hline April & $\$ 324$ & $\$ 252$ & $\$ 247$ \\
\hline May & $\$ 380$ & $\$ 212$ & $\$ 274$ \\
\hline June & $\$ 382$ & $\$ 255$ & $\$ 226$ \\
\hline July & $\$ 430$ & $\$ 224$ & $\$ 219$ \\
\hline
\end{tabular}

The potential lost revenue from not using a dynamic pricing model was then calculated. Lost revenue was determined by calculating the difference between estimated concert revenue from initial selling prices and revenue if tickets had been sold at average secondary market prices (assuming dynamic pricing). Initial selling prices for the two-show concerts in 2016 and 2018 were calculated by using an average between the two selling prices. The calculations use the Wrigley Field concert capacity number of 41,000 . Table 3 displays potential lost revenue results.

TABLE 3

POTENTIAL LOST REVENUE

\begin{tabular}{|c|c|c|c|}
\hline Concert & Revenue & $\begin{array}{c}\text { Revenue using } \\
\text { Average Secondary } \\
\text { Market Price }\end{array}$ & $\begin{array}{c}\text { Potential Lost } \\
\text { Revenue }\end{array}$ \\
\hline 2013 & $\$ 2.75$ million & $\$ 14.3$ million & $\$ 11.5$ million \\
\hline 2016 & $\$ 6.56$ million & $\$ 18.5$ million & $\$ 11.94$ million \\
\hline 2018 & $\$ 10.62$ million & $\$ 19.9$ million & $\$ 9.3$ million \\
\hline Total Potential \\
Lost Revenue
\end{tabular}

\section{CONCLUSION}

As shown by the total potential lost revenue for the five Pearl Jam concerts at Wrigley Field in 2013, 2016 , and 2018 of $\$ 32.6$ million, dynamic pricing models in the concert industry can significantly impact artist revenue maximization and who receives those revenues. This result is consistent with the thoughts of Gary Bongiovanni, the editor-in-chief of concert trade publication Pollstar, as quoted in the April 9, 2018 edition of Rolling Stone, “the industry is adopting a new mantra, if you sell out quickly, you didn't price tickets properly".

The study did note an "over reaction effect", where initial secondary market purchasers reacted disproportionately to the quick concert sell-outs. Thus, those prices did not reflect the ticket's "true value" immediately following the initial sale. Consistent with previous studies of market efficiency in securities markets, the price swing from overreaction was not long lasting. Ticket prices returned back to lower values value after initial purchases on the secondary market - 7-13 percent less in subsequent months after initial sales. 


\section{REFERENCES}

Bongiovanni (2018). Taylor Swift's Ticket strategy: brilliant business or slowing demand. Rolling Stone. April 9, 2018.

Carroll and Grimes (1995). Evolutionary Change in product management experiences in the car rentalindustry. Interfaces, 25(5), 84-104.

Courty, P. (2000). An economic guide to ticket pricing in the entertainment industry. Louvain EconomicReview, 66(1), 167-191.

Courty, P. (2003). Some economics of ticket resale. Journal of Economic Perspectives, 17, 85-97.

De Bondt, W. and Thaler, R. (1989). Anomalies: a mean reverting walk down wall street. Journal ofEconomic Perspectives, 3(1), 189-202.

Drayer, J. and Shapiro, S.L. (2009) Value determination in the secondary market: a quantitative analysisof the NFL playoffs. Sports Marketing Quarterly, 18(1), 5-13.

Gelbrich, K. (2011). I have paid less than you! The Emotional and behavioral consequences of advantaged price inequality. Journal of Retailing, 87(2), 207-224.

Hanks, R.B., Nolan, R.P. and Cross, R.G. (1992). Discounting in the hotel industry, a new approach.Cornell Hotel and Restaurant Administration Quarterly, 33(3), 40-45.

Kimes, S.E and Wirtz, J. (2003). Perceived fairness of revenue management in the US golf industry. Journal of Revenue and Pricing Management, 1(4), 332-344.

Krueger, A.B. and Pray, M.C. (2008). Evidence on the secondary market for concert tickets. Canadian Economics Association - First Draft.

Rozeff, M and Kinney, W. (1976). Capital market seasonality: the case of stock returns. Journal of Financial Economics, 3, 379-402.

Seabrook, J. (2009, August 10). The price of the ticket. New Yorker. pp. 34-43.

Shapiro, S.L, Drayer, J. and Dwyer, B. (2016). Examining consumer perceptions of demand-based ticket pricing in sport. Sports Marketing Quarterly, 25, 34-46.

Smith, B.A., Leimkuhler, J.F., and Darrow, R.M. (1992). Yield management at American airlines. Interfaces, 2(1), 8-31.

Volpano, L.J. (2003). A proposal to rationalize entertainment ticket pricing using price discrimination. Journal of Revenue and Pricing Management, 1(4), 379-382.

Weisstein, F.L., Monroe, K.B., and Kukar-Kinney, M. (2013). Effects of pricing framing on consumers' perceptions of online dynamic pricing practices. Journal of the Academy of Marketing Science, 41, 501-514. 